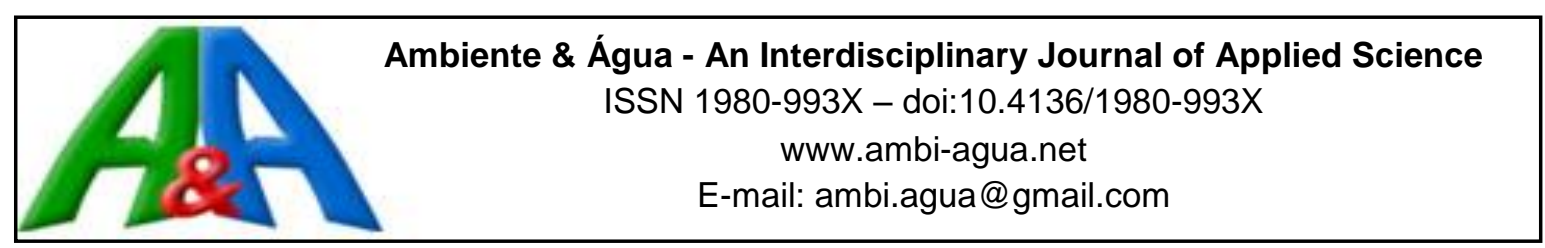

\title{
Removal of organic matter from pre-treated domestic sewage in anaerobic biological reactor by a combined system of electrolytic and biological aerobic treatment
}

\author{
ARTICLES doi:10.4136/ambi-agua.2349
}

Received: 26 Nov. 2018; Accepted: 10 Jun. 2019

\author{
Ariela Araujo Fonseca* ${ }^{(D)}$; Yovanka Pérez Ginoris ${ }^{(D)}$ \\ Norma Mendes Pinheiro Gontijo ${ }^{(D)}$; Marco Antonio Almeida de Souza \\ Universidade de Brasília (UnB), Brasília, DF, Brasil \\ Departamento de Engenharia Civil e Ambiental (ENC). \\ E-mail: ariela_fonseca@hotmail.com, yovanka.perez@gmail.com, \\ normabiomed@gmail.com, marcantoniosouza@gmail.com \\ "Corresponding author
}

\begin{abstract}
Biological processes are the most widespread methods for wastewater treatment. However, they are limited in their ability to degrade toxic and refractory pollutants, contaminants that electrochemical processes can remove. Therefore, this research explored the possibility of treating sewage by an anaerobic biological process followed by an aerobic system integrated to an electrolytic process. Three sequential batch reactors were operated in an automated way. Each of three reactors represented a process: aerobic biological treatment (BR); electrolytic treatment (ER); and a combination of both, the bio electrolytic reactor (BER). Two phases were ran with different electrodes: (Phase 1) stainless steel and (Phase 2) graphite. The electric current was varied from 0.001 to $0.100 \mathrm{~A}$. COD, TS, SS, turbidity, and the zooplankton community were monitored. The highest organic matter removal efficiencies were $86 \%, 79 \%$ and $87 \%$ for BR, ER and BER, respectively. The best weekly BER efficiencies for COD removal were $90 \%$ and $98 \%$, with current densities of $0.27 \mathrm{~A} / \mathrm{m}^{2}$ (Phase 1) and $0.05 \mathrm{~A} / \mathrm{m}^{2}$ (Phase 2). The main conclusions about bio electrolytic process were: (1) it did not achieve organic matter removal high enough to justify its application; (2) inert electrodes are the more indicated; and (3) the zooplankton community was affected by the electric current.
\end{abstract}

Keywords: bioelectrolytic reactor, electrolytic treatment, removal of organic matter.

\section{Remoção de matéria orgânica de esgoto doméstico pré-tratado em reator biológico anaeróbio por um sistema combinado de tratamento eletrolítico e biológico aeróbio}

\section{RESUMO}

Os processos biológicos são os métodos mais difundidos para o tratamento de águas residuárias. No entanto, eles têm limitações para degradar poluentes tóxicos e refratários, contaminantes, que os processos eletroquímicos podem remover. Portanto, o objetivo da pesquisa foi verificar a possibilidade de tratamento de esgoto por um processo biológico anaeróbio seguido de um sistema aeróbio integrado a um processo eletrolítico. Três reatores 
sequenciais em batelada foram operados de maneira automatizada. Cada um dos três reatores representou um processo: tratamento biológico aeróbico (RB); tratamento eletrolítico (RE); e a fusão de ambos, o reator bioeletrolítico (RBE). Duas fases foram executadas com diferentes eletrodos: (Fase 1) de aço inoxidável e (Fase 2) de grafite. A corrente elétrica foi variada de 0.001 a 0.100 A. DQO, ST, SS, turbidez e comunidade zooplanctônica foram monitorados. As maiores eficiências de remoção de matéria orgânica foram $86 \%, 79 \%$ e $87 \%$ para BR, RE e $\mathrm{RBE}$, respectivamente. As melhores eficiências semanais de RBE para remoção de DQO foram $90 \%$ e $98 \%$ com densidades de corrente de $0.27 \mathrm{~A} / \mathrm{m}^{2}$ (Fase 1) e $0.05 \mathrm{~A} / \mathrm{m}^{2}$ (Fase 2). As principais conclusões sobre o processo bioeletrolítico foram: (1) eles não atingem remoção de matéria orgânica tão alta que justifique sua aplicação; (2) os eletrodos inertes são os mais indicados; e (3) a comunidade zooplanctônica foi afetada pela corrente elétrica.

Palavras-chave: reator bioeletrolítico, remoção de matéria orgânica, tratamento eletrolítico.

\section{INTRODUCTION}

The most-used processes for sewage treatment are biological treatments. However, these treatment processes have limitations in the removal of organic matter and solids, require a great deal of space, are time-consuming, and do not tend to be entirely effective against barely biodegradable and toxic pollutants (Martínez-Huitle et al., 2015). Further, biological methods also give low degradation efficiency in the treatment of highly concentrated and biorefractory pollutants, especially certain industrial wastewaters containing toxic components such as pesticides, because the activity of microorganisms is inhibited by toxicity. To treat this kind of wastewater, many physical and chemical methods have been introduced (Liu et al., 2010). In relation to anaerobic treatment, its effluents have high BOD concentrations, color and unpleasant odor, resulting in the need for complementary treatment. Therefore, there is a global trend to improve existing sewage treatment processes and continuously enhance the quality of treated effluents, with the purpose of adapting them to environmental requirements and water reuse.

Electrolytic treatment is one of the complementary alternatives to anaerobic biological treatment. In the last few years, electrolytic treatment was associated with the anaerobic or aerobic biological treatment. According to Ganzenko et al. (2014), these combined processes are studied before or after electrolytic treatment. In the first case, the goal is to make biodegradable the effluent for subsequent biological treatment. In the second case, the electrolytic process is located after the biological treatment to remove pollutants and their intermediates, which are refractory to anaerobic bacteria. Electrolytic treatment can reduce the effluents' toxicity by transforming persistent substances into biodegradable substances. In addition to the efficiency of electrolytic treatment, this kind of sewage treatment also has several advantages: it uses compact reactors with a smaller physical footprint requiring less landspace; there is no need for auxiliary chemicals, which obviates the need to store and transport such chemicals it can be easily combined with other conventional water treatment technologies; and it can be fully automated (Garcia-Segura et al., 2018).

Electrolytic treatment therefore allows the increasing of the efficiency of conventional biological treatment (Claro et al., 2010). Electrolytic processes have been an option for the wastewater treatment, and they can be used as a single process or coupled with other processes. This type of treatment can be adapted to various applications and can be easily combined with other technologies, and its modular and compact design makes it attractive for the treatment of decentralized wastewater (Radjenovic and Sedlak, 2015). Materials commonly used to make the electrodes are aluminum or iron, because they are cheap and easy to access. However, other materials have been studied, such as oxides of graphite, titanium, ruthenium, platinum, copper

Rev. Ambient. Água vol. 14 n. 4, e2349 - Taubaté 2019 
and zinc. When an electrode, during the electrolysis process, does not undergo changes in its structure, even under certain conditions, it is called an inert electrode and its function is the simple exchange of electrons with the solution; examples of inert electrodes are graphite and platinum. The active electrode, besides transferring electrons, chemically participates in electrolysis, being also modified by the action of the electric current, forming metallic ions; examples of active electrodes are iron and copper. In oxidation processes, researchers have been using graphite electrodes, because of their high porosity, which results in a larger surface area. In addition, electrodes composed of platinum, aluminum and steel have been extensively applied (Mattiusi et al., 2015).

The main purpose of this paper was to study the possibility of performing the effluent treatment of an anaerobic biological system by the aerobic biological treatment combined with the electrolytic process, known as bio electrolytic treatment. Another purpose was to verify if there is synergy between the aerobic biological process and the electrolytic process for the removal of organic matter from sewage. In addition, the zooplankton community was evaluated and compared in the aerobic biological process and in the integrated bio electrolytic process, and relations were explored between the relative abundances of the organisms groups with the performance of the sewage treatment processes.

\section{MATERIALS AND METHODS}

\subsection{Design and construction of the bench scale electrolytic system}

Figure 1 shows the schematic diagram of the experimental apparatus for operating the bench scale electrolytic system that was conceived for this research. A photograph of the complete experimental system installed in the laboratory can be seen in Figure 2. The system was composed of three glass reactors of 4 liters volume each; the useful volume was $3.6 \mathrm{~L}$. The adopted configuration was an activated sludge as an aerobic biological reactor (BR), an electrolytic reactor (ER) and a bio electrolytic reactor, which combined the two processes, activated sludge and electrolytic (BER). The system ran in an automated way and in sequential batches, each reactor running in parallel with others. The system operation was divided into two operational phases. In each phase, the type of electrodes used was alternated. At the first phase, as electrodes, brushed stainless steel $\mathrm{n}^{\circ} 430$, was used with a size of $13 \times 14 \mathrm{~cm}$, a thickness of $1.0 \mathrm{~mm}$, a density of $7.8 \mathrm{~g} / \mathrm{cm}^{3}$, and a resistivity of $0.06 \mu \Omega \mathrm{m}$. In the second phase of operation, the electrode applied was the pure graphite plate with density of $1.75 \mathrm{~g} / \mathrm{cm}^{3}$, resistivity of $7.5 \mu \Omega \mathrm{m}$, size of $13 \times 14 \mathrm{~cm}$, and thickness of $2.7 \mathrm{~mm}$. The automatic operation of the system was possible due to an Arduino microcontroller. This device had the function of controlling the operation of the cycles in the sequential batches, as well as the duration times of each batch phase, the filling and discharge of the reactors, activation of the aerators and the electric source. An Arduino Mega 2560 R3 was used due to the cost of acquisition and to fit the technical needs.

\subsection{Experimental design}

Due to the large variation in the domestic wastewater composition, synthetic wastewater (SW) was used to simulate domestic sewage pretreated by an anaerobic treatment. For this purpose, the effluent of a local study (Achaval, 2014) was chosen. Achaval (2014) developed a prototype of a compact wastewater treatment plant for single-family residential units. For the preparation of SW, the methodology used was that proposed by Torres et al. (1996) and used by Moura (2011) and Michelan (2006). For this research, an SW was used with approximately $265 \mathrm{mg}$ COD. $\mathrm{L}^{-1}$. The inoculum used in the first and second phase was the mixed liquor collected and transported from the return well of a biological aerobic reactor of the Sewage Treatment Plants of Brasília - South and North, respectively. 


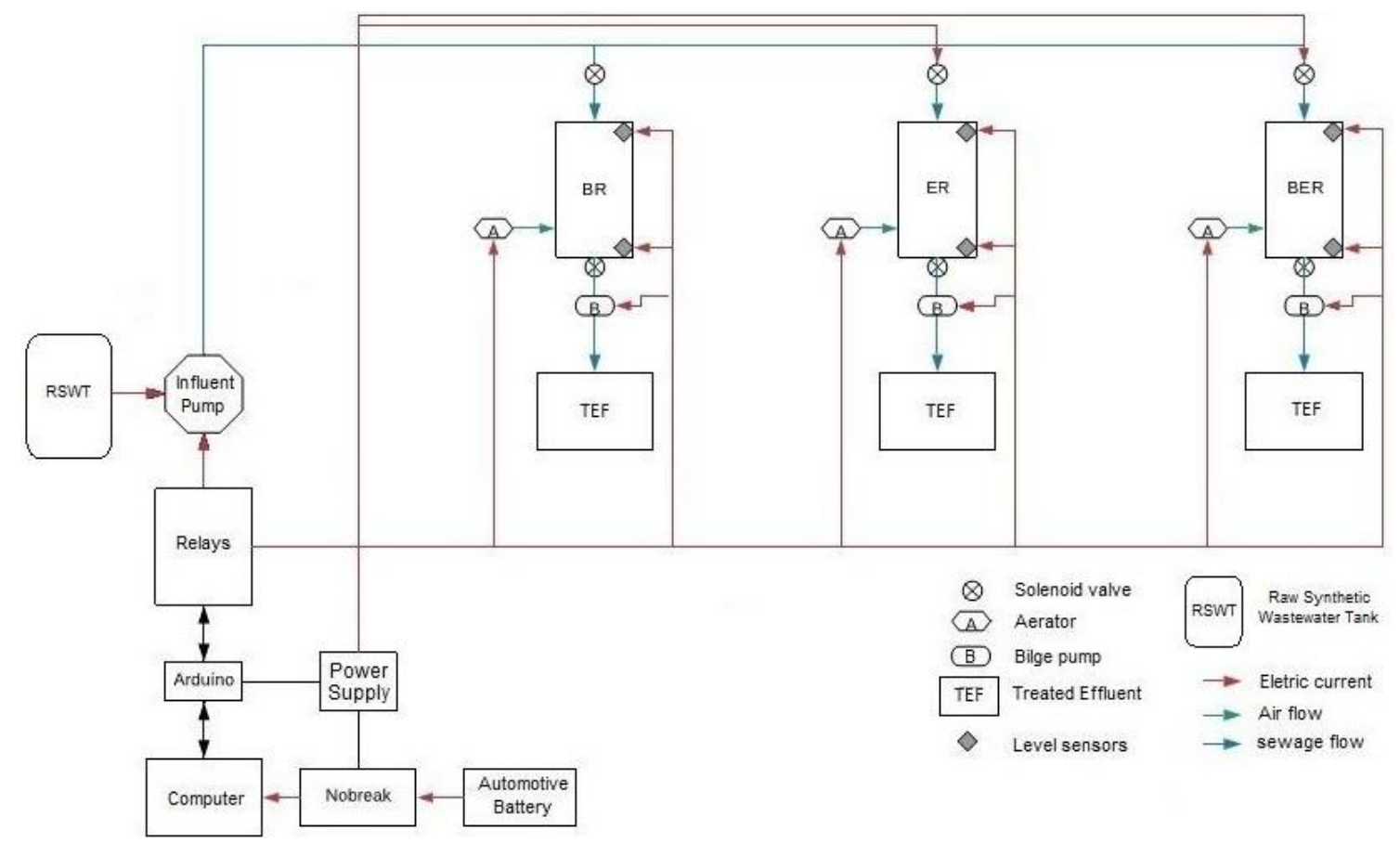

Figure 1. Schematic diagram of the experimental apparatus.

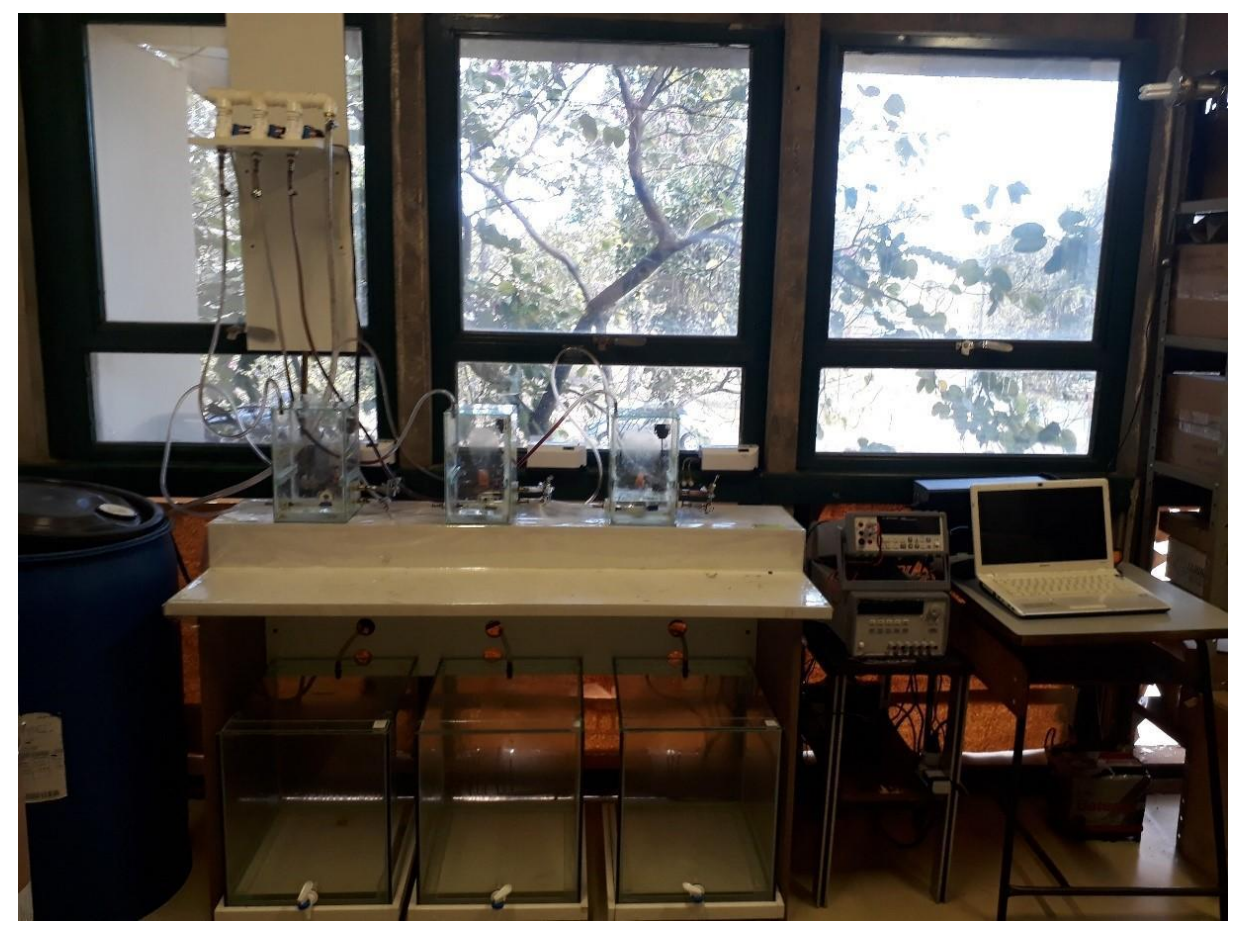

Figure 2. Photograph of the complete experimental system installed in the laboratory.

For the beginning of reactors operation, the inoculum was brought and introduced in the BR and the BER reactors, transferring the amount of 1.08 liters per reactor, equivalent to $30 \%$ of the useful volume of each reactor. During the day, the system was operated in two batches of three hours of reaction and one hour of sedimentation, totaling 4 hours of duration for each batch. During the night, only a single batch was carried out for 12 hours, with 11 hours of reaction and 1 hour of sedimentation. The filling and disposal steps were performed quickly at the beginning and end of each batch. This operation model was chosen to prevent system 
interruptions caused by failures in the electric power supply, which would result in the system reboot. In addition, the prototype operation model tried to reproduce a single-family sewage treatment system, in which during the night period the inlet flow is small or non-existent, resulting in a long duty cycle at night. Each system operational phase was fixed in 25 days. Every 5 days a different electric current was applied. Each application of electrical current band started on Monday and ended on Friday. There were no electric current applications on weekends. Each band of electric current applied weekly was called the "experimental condition". Therefore, a different experimental condition was applied each week of operation, which corresponds to the electric current ranges previously defined for the experiment. The current ranges were suggested according to the electric source specifications and the literature studied. Concerning the current variation in the reactors and the operation of each cycle, it is possible to understand the operation model in Tables 1 and 2.

Table 1. Operation of Biological Reactor (BR), Electrolytic Reactor (ER) and Bio Electrolytic Reactor (BER).

\begin{tabular}{lcccccc}
\hline Stages of the cycle & Duration & \multicolumn{2}{c}{ Electric Current (A) } & Aeration & \multicolumn{3}{c}{ Electrical Current (status) } \\
\hline & & BR, ER e BER & & BR & ER & BER \\
\hline Filling & $1 \mathrm{~min}$ & - & On & Off & Off & Off \\
Reaction & $180 \mathrm{~min}$ & 0.001 a 0.100 & On & Off & On & On \\
Sedimentation & $60 \mathrm{~min}$ & - & Off & Off & Off & Off \\
Disposal of effluent & $2 \mathrm{~min}$ & - & Off & Off & Off & Off \\
\hline
\end{tabular}

Table 2. Experimental conditions, current ranges and currents densities applied to the system during the operational phases.

\begin{tabular}{ccc}
\hline Experimental Conditions & Current ranges (A) & Current densities $\left(\mathbf{A} / \mathbf{m}^{2}\right)$ \\
\hline $\mathbf{1}^{\circ}$ Condition & 0.001 & 0.0549 \\
$\mathbf{2}^{\circ}$ Condition & 0.005 & 0.2747 \\
$\mathbf{3}^{\circ}$ Condition & 0.010 & 0.5494 \\
$\mathbf{4}^{\circ}$ Condition & 0.050 & 2.7473 \\
$\mathbf{5}^{\circ}$ Condition & 0.100 & 5.4945 \\
\hline
\end{tabular}

\subsection{Sampling and analyses performed on the effluent}

Samples were collected daily and weekly. The sample collection was carried out in the effluent inside the reactors (mixed liquor) and in the treated effluent. Sampling was performed in a composite manner, starting from the first cycle of the day. Simple samples were collected each cycle, and at the end of the day, the samples were homogenized and transferred to a specific bottle and refrigerated until the next day. This procedure was carried out from Monday to Thursday; on Friday, the samples collected were acidified to retain their characteristics until the analysis performed on Monday. All analysis were performed according to the standards established by the Standard Methods for the Examination of Water and Wastewater (APHA et $a l ., 2005)$. The analysis performed and the method followed for each one can be visualized in Table 3.

Table 3. Analysis performed on mixed liquor (ML) and effluent (EF).

\begin{tabular}{lccc}
\hline Parameter to be analyzed & Point of collect & Weekly frequency & Method \\
\hline Chemical demand for oxygen & EF & Daily & Colorimetric \\
Total suspended solids & ML / EF & 1 & Gravimetric \\
Turbidity & EF & 2 & Nephelometric Method \\
Dissolved oxygen & ML & Daily & Oximeter \\
Count of microorganisms & ML & 2 & Method of Madoni (1994) \\
\hline
\end{tabular}


As in the activated sludge system, the low illumination condition is not favorable for the development of the phytoplankton community; it was chosen to observe only the zooplankton community. Zooplankton monitoring was performed by the identification and counting of protozoa and metazoan, always in duplicate, presented in the mixed liquor of the BR and BER reactors. For each experimental condition, two micro fauna analysis corresponding to the beginning and the end of the electric current application in the reactors were performed. For identification and counting of zooplankton, the methodology proposed by Madoni (1994) was followed. In order to characterize the zooplankton community present in the mixed liquor of the BR and BER reactors, the proper systematics for typical microorganisms of activated sludge systems was used, as proposed by Canler et al. (1999) and Madoni (1994). For this characterization, microorganisms were identified up to the gender level, and were grouped into eight groups as follows:

- Amoebas: Represented by the naked amoebas and testae amoebas of the Arcella genus;

- Annelids: Represented by order oligochaeta, Aelosoma genus;

- Crawling ciliates: Represented by aspidisca, chilodonella, drepano monas, Trachelophyllum and Trochilia genuses;

- Free swimming ciliates: Represented by the genera Colpidium, Tetrahymena and Litonotus;

- Attached Ciliates: Represented by Epistylis, Vorticella, Podophrya, Tokophrya and Acienta genuses;

- Big flagellates: Represented by Peranema genus;

- Nematode: Represented by Nematodes genus; and

- Rotifers: Represented by Digononta e Monogononta orders;

To facilitate the results exhibition in the graphs, the groups of organisms were abbreviated. Table 4 shows abbreviation subtitles.

Table 4. Subtitle of the names of the groups of microorganisms.

\begin{tabular}{lc}
\hline Organism & Abbreviation \\
\hline Amoebae & AM \\
Annelids & AN \\
Crawling ciliates & CC \\
Free swimming ciliates & FSC \\
Attached Ciliates & AC \\
Big Flagellates & BF \\
Nematodes & NE \\
Rotifers & RO \\
\hline
\end{tabular}

\section{RESULTS AND DISCUSSION}

The use of electrodes of different materials promoted changes in the characteristics of treated effluents. The first phase (with stainless steel) lasted four weeks due to operational problems. The second phase (with pure graphite) ran normally under the predicted conditions during five weeks. Table 5 shows the weekly COD removal efficiency values obtained at the three points analyzed during the two operational phases. 
Table 5. Weekly medium COD removal efficiency values, obtained at the three points analyzed during the two phases of the experimental system operation.

\begin{tabular}{lcccccc}
\hline \multicolumn{7}{c}{ COD Removal Efficiency (\%) } \\
\hline & $\mathbf{1}^{\circ}$ phase (with stainless steel) & \multicolumn{2}{c}{$\mathbf{2}^{\circ}$ phase (with pure graphite) } \\
\hline & BR & ER & BER & BR & ER & BER \\
\hline $\mathbf{1}^{\circ}$ Week & 90.44 & 81.35 & 78.09 & 95.10 & 67.60 & 98.20 \\
$\mathbf{2}^{\circ}$ Week & 82.01 & 53.90 & 89.69 & 87.40 & 70.30 & 85.70 \\
$\mathbf{3}^{\circ}$ Week & 85.14 & 65.88 & 80.77 & 79.20 & 73.20 & 81.00 \\
$\mathbf{4}^{\circ}$ Week & 78.35 & 77.07 & 72.45 & 83.70 & 90.20 & 80.90 \\
$\mathbf{5}^{\circ}$ Week & - & - & - & 82.00 & 92.20 & 88.20 \\
\hline
\end{tabular}

$\mathrm{BR}=$ Biological reactor, $\mathrm{ER}=$ Electrolytic reactor, $\mathrm{BER}=$ Bioelectrolytic reactor.

It was noticed that the BER best performance in the first phase was reached on the second week of operation, while in the second phase the best performance occurred in the first week. In the first phase, reactive electrodes of stainless steel were used, so it is probable that, due to the electrolysis process, part of the iron that comprises this electrode has been lost in the water, added to the sludge and precipitate, avoiding that it was discarded with the effluent. According to Al-Shannag et al. (2013), when iron is used in the electrocoagulation process, the formation of Fe (III) ions is favorable. In a basic environment, simultaneous formations of ferric hydroxide/oxides are also expected. Precipitates of formed $\mathrm{Fe}$ (III) hydroxides have a coagulating character better than Fe (II) hydroxide, because $\mathrm{Fe}(\mathrm{OH})_{3}$ is more stable than $\mathrm{Fe}(\mathrm{OH})_{2}$, so the removal efficiency increases. It is important to note that the samples submitted to the COD tests were aerated during the batch reaction phase. This suggests that the effluent from the ER and BER reactors contained only $\mathrm{Fe}^{3+}$, which does not interfere in the COD test because these cations are in their maximum oxidation state. In the second phase, where graphite electrodes were used, the optimum efficiency value was reached in the first week. This can indicate that, with a current equivalent to $0.001 \mathrm{~A}$, the microorganisms may not have been affected abruptly and current may have acted on a positive threshold for the micro fauna. However, in the first and second phases, during the weeks of operation, there were oscillations in COD removal performances, suggesting that the microorganisms present in the BER reactor may have been affected by the variations and increasing of the electric current.

Regarding the ER reactor in the first phase of operation, the best COD removal performance occurred in the first week. In the second phase, it occurred in the last operational week. The result obtained in the first phase was unexpected, because in the electrolytic treatment the higher the electric current applied, the greater the treatment efficiency. However, considering the usage of stainless steel electrodes in this phase, it is known that due to the oxidization of the electrode, an iron release occurs which may have caused interference in the COD analysis.

In the second phase, it was noticed that, with the increase of the electric current during the weeks of operation, the ER reactor's COD removal efficiency increased, confirming the premise of the electrolytic treatment. The COD reduction in the ER reactor increased with current density. This can be explained by the increase in the release of metallic ions with the increase in current density, which improves COD reduction. (Senthilkumar et al., 2012). The BR reactor showed similar behavior in the two phases of operation. There were fluctuations in the removal values and a pattern of decreased performance was noted over the weeks of operation. This fact suggests an affectation of the microbial community in the BR reactor probably due to operational factors.

The overall COD removal performance in the first phase of the four weeks of operation were $84 \%, 70 \%$ and $80 \%$ of COD removal in BR, ER and BER reactors, respectively. In the 
second phase, overall performance removal of the five weeks of operation was $85 \%, 79 \%$ and $87 \%$ in the reactors BR, ER and BER, respectively. The best performance was obtained in the second phase of operation, and BR and BER reactors presented similar results. The performance achieved by the BR reactor in the first and second phases, 84 and $85 \%$ of COD removal, was lower than that demonstrated by Santos (2005), who worked with Sequential Batch Reactor (SBR) under different sludge ages in bench scale for domestic wastewater treatment and reached $90 \%$ in COD removal. The BR reactor performances in both phases also were lower than that achieved by Chonova et al. (2016), who evaluated the efficiency of biological treatment with a conventional activated sludge system for domestic wastewater treatment and reached 95.4\% COD removal. Comparing this reactor with a full-scale plant, it was found that the BR reactor also had an efficiency lower than expected, since the activated sludge reactor of the Brasília South Sewage Treatment Plant obtained a COD removal of 92.4\% in the year 2013 (CAESB, 2013). The oscillations in COD removal efficiencies in the BR reactor in the two phases can be attributed to the model of operation adopted in the system. During the night, only a single and long batch was carried out for 12 hours, with 11 hours of reaction and 1 hour of sedimentation. Therefore, it can be considered that the biomass was affected and the F/M ratio was reduced drastically overnight due to batch duration. According to Von Sperling (1997), when the F/M ratio is low, when the amount of food supplied to biomass is reduced, the endogenous respiration rate prevails in the system. In this case, in order to ensure the survival of microorganisms, oxygen consumption by the cells occurs to degradation of the substrate present in the bacterial cell itself.

On the other hand, the COD removal efficiency reached by ER reactor was $70 \%$ in the first phase. This result is close to that of the research of Rodrigues et al. (2001), who worked with iron and aluminum electrodes treating effluent from a UASB reactor and obtained COD removal efficiency of $74.74 \%$ in the reactors. This result also is compatible with the results obtained by Daghrir et al. (2014), who worked with bored doped diamond anodes treating effluent from domestic wastewater and obtained COD removal efficiency of $78.2 \%$. Furthermore, the work of Al-Shannag et al. (2013) may be cited, who operated a system to enhance the COD and nutrient removal of a secondary clarifier of municipal wastewater, using electrocoagulation technique with an iron electrode, and obtained steady removal efficiencies of COD and nutrients exceeding $89 \%$, surpassing the result of this research. In the second phase, the efficiency result of the ER reactor was higher than that of Rodrigues et al. (2001), very close to that found by Daghrir et al. (2014), and smaller than that found by Al-Shannag et al. (2013). Briefly, in the second phase, due to the characteristics of the electrodes, since they were inert, it was noticed that the increase of the COD removal occurred with the increase of the electric current, according to the rules of electrolysis. In the integrated biological and electrolytic process, Senthilkumar et al. (2012) obtained 80\% COD removal, the same result reached by the BER reactor in the first phase and lower than that of the second phase, which was $87 \%$.

Regarding the efficiency of Total Suspended Solids (TSS) removal, in the first phase $93 \%$ was removed in the BR, $47 \%$ in the ER and $95 \%$ in the BER reactor. In the second phase, the results were $84 \%$ in the BR, $38 \%$ in the ER and $76 \%$ in the BER reactor. It can be stated that the highest values of TSS removal were reached in the decantation of the BR and BER effluents. This was possibly due to the optimum sedimentation of the effluent and due to the fact that the reactors have biological solids inside them. In the first phase, there was the aggregation of dissolved iron in the BER biomass, promoting the retention of part of the solids inside the reactor. In the ER, the mean removal was lower during the two phases, which may have been caused by the accumulation of material from the SW inside the reactor.

The turbidity results obtained in the treated effluents of the reactors indicate that the values corresponding to the effluent from the biological reactor were similar in the two phases, 9 and

Rev. Ambient. Água vol. 14 n. 4, e2349 - Taubaté 2019 
8 NTU (Nephelometric Turbidity Unit), for the first and the second phase. However, in the first phase of operation, the highest discrepancy between turbidity values of the effluents was observed, 5 and 40 NTU for the ER and the BER, and in the second phase, the values were 13 and 11 NTU. The discrepancy between the values of the first and second phases can be attributed to the use of reactive electrodes and to their rapid wear. Concerning dissolved oxygen (DO) concentrations in the reactors, it was verified that the values were above $2 \mathrm{mg} . \mathrm{L}^{-1}$, the minimum concentration recommended by the USEPA (1993). In the first phase, the DO concentration remained at $5.75 \mathrm{mg} . \mathrm{L}^{-1} \mathrm{O}_{2} \pm 0.73$ in the $\mathrm{BR}$ and $6.14 \mathrm{mg} . \mathrm{L}^{-1} \mathrm{O}_{2} \pm 0.29$ in the BER reactor. In the second phase, these values were $5.99 \mathrm{mg} . \mathrm{L}^{-1} \mathrm{O}_{2} \pm 0.27$ and $5.95 \mathrm{mg} . \mathrm{L}^{-1} \mathrm{O}_{2}$ \pm 0.30 in the BR and the BER reactors, respectively. Therefore, aeration conditions were maintained for the development of heterotrophic aerobic biomass in the reactors.

The first phase of operation lasted four weeks. Consequently, four experimental conditions were applied in this phase, because each week represented an experimental condition. Stainless steel electrodes were used. In each week of operation two micro fauna analysis corresponding to the beginning and the end of the current application in the BR reactors and the BER were carried out. In the second stage of operation, pure graphite rigid electrodes were used. This phase lasted five weeks, where five experimental conditions were applied. However, the quantitative and qualitative characterization of the biomass began to be performed from the second week of operation, which represents the second experimental condition applied.

During the first operational phase, there were significant variations in the reactors' micro fauna. At the beginning of the first week of operation, corresponding to the first experimental condition, it was observed that in the two reactors, BR and BER, there was little variety of group of organisms (Figure 3). However, Monogononta and Digononta, organisms of the rotifers class, presented themselves as dominant species. At the end of the period, an increase in micro fauna diversity and in the ciliates relative frequency was noticed, accompanied by a reduction in the abundance of rotifers.

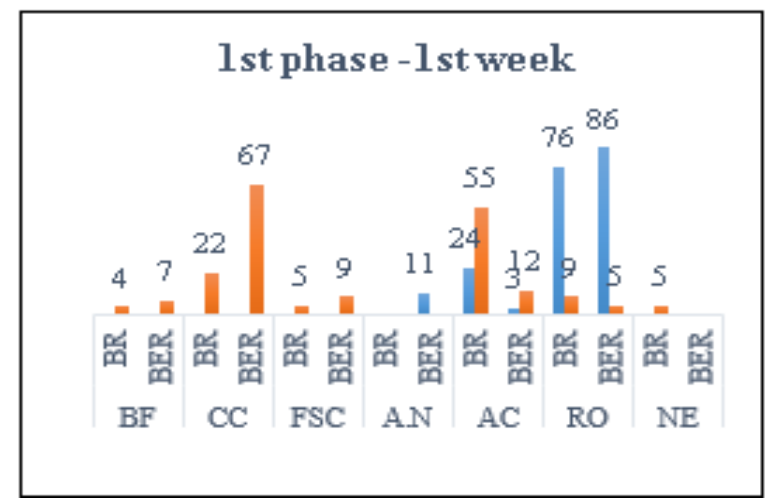

Figure 3. Microorganisms relative frequency in $\mathrm{BR}$ and BER of the third week of operation corresponding to the third experimental condition applied. The labels of the organisms are in accordance with Table 4.

In the beginning of the second experimental condition, at the first phase, the crawling ciliates appeared with the highest relative frequencies in the BR and BER reactors (Figure 4). At the end of the period, it was noticed that species diversity was affected in the two reactors, but the BR was more affected. It was also noticed that the amoebas became dominant in the BR and BER reactors. During this experimental condition, at the second phase, it was noticed at the beginning that the dominant groups were rotifers and attached ciliates, in the BR and BER reactors. However, at the end of this period the attached ciliates, a dominant species at the 
beginning of the week, gave way to the rotifers and swimming ciliates, which predominated in the BER. This behavior was similar in the two reactors, so this fact was not due to the electric current application.

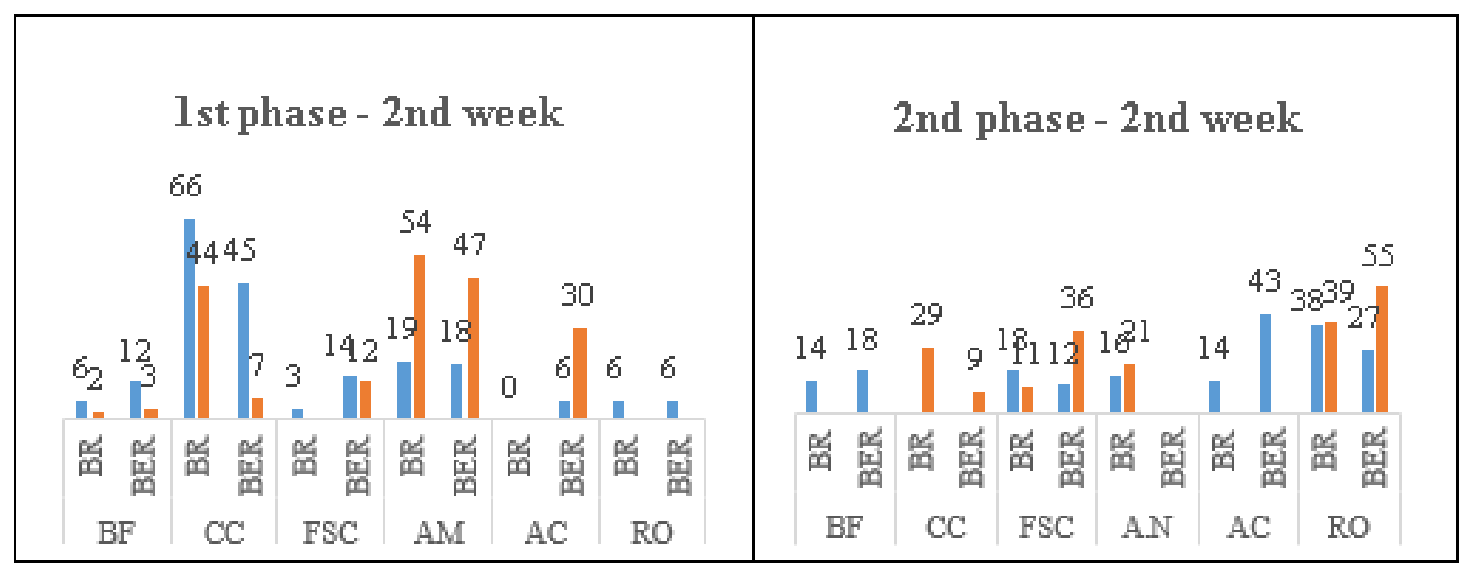

Figure 4. Microorganisms' relative frequency in the BR and BER during the second week of operation, corresponding to the second experimental condition applied. The labels of the organisms are in accordance with Table 4.

During the third experimental condition, at the first phase, at the beginning it was observed that the two reactors presented similar diversity (Figure 5). At the end of this period, no affectation of the microorganisms was observed with respect to their diversity, being that the predominant class in the reactors was the attached ciliates of the genus Epistylis. In the third experimental condition, at the second phase, a decrease in the number of species of microorganisms presented in the BER reactor was observed. The BR reactor remained stable in relation to the diversity of groups present. At the end of this period, there was a recovery of the reactors with the development of species and with the increase of the microorganisms diversity.

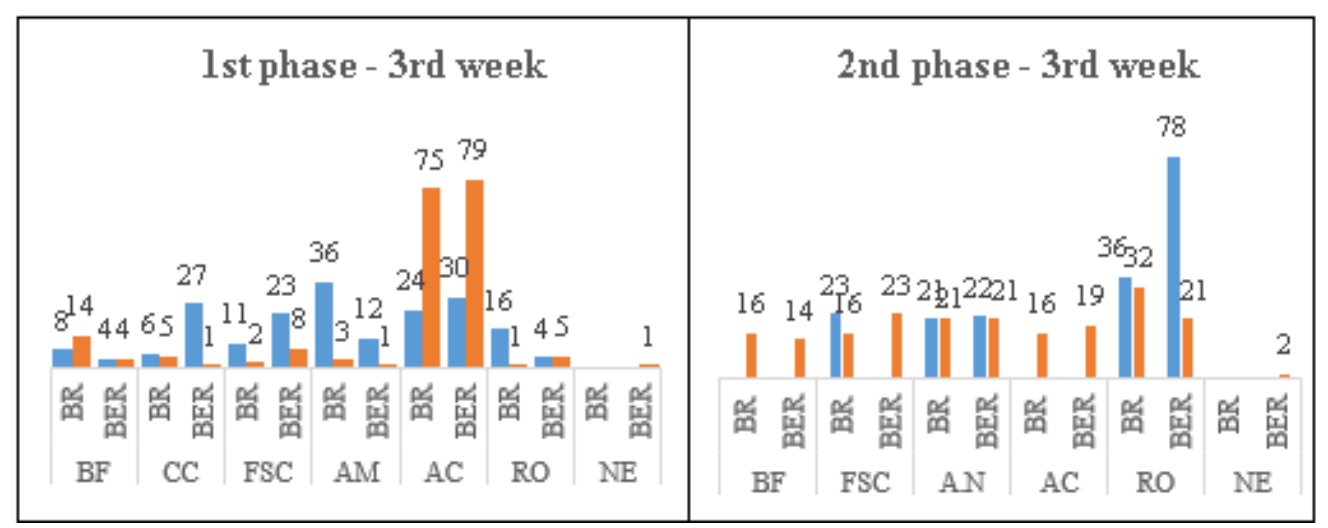

Figure 5. Microorganisms' relative frequency in the BR and BER during the third week of operation, corresponding to the third experimental condition applied. The labels of the organisms are in accordance with Table 4.

Still referring to the first phase of operation, in the fourth experimental condition, the attached ciliates were the dominant species, but in the BER, also amoebas and nematodes were found (Figure 6). The rotifers and annelids disappeared in the BER, whereas in the RB the relative frequencies of these organisms increased, a fact that reinforces the possibility of the electric current influencing the microorganisms. The reduction of rotifers and annelids in BER may be indicative of damage to the system performance once these organisms represent satisfactory aeration conditions and effluent quality. During the fourth experimental condition,

Rev. Ambient. Água vol. 14 n. 4, e2349 - Taubaté 2019 
at the second phase, the predominance of rotifers and annelids in both reactors was observed. At the end of the period, it was noticed that the rotifers were dominant in the BER. However, there was an annelids community increasing, represented by Aelosomas.

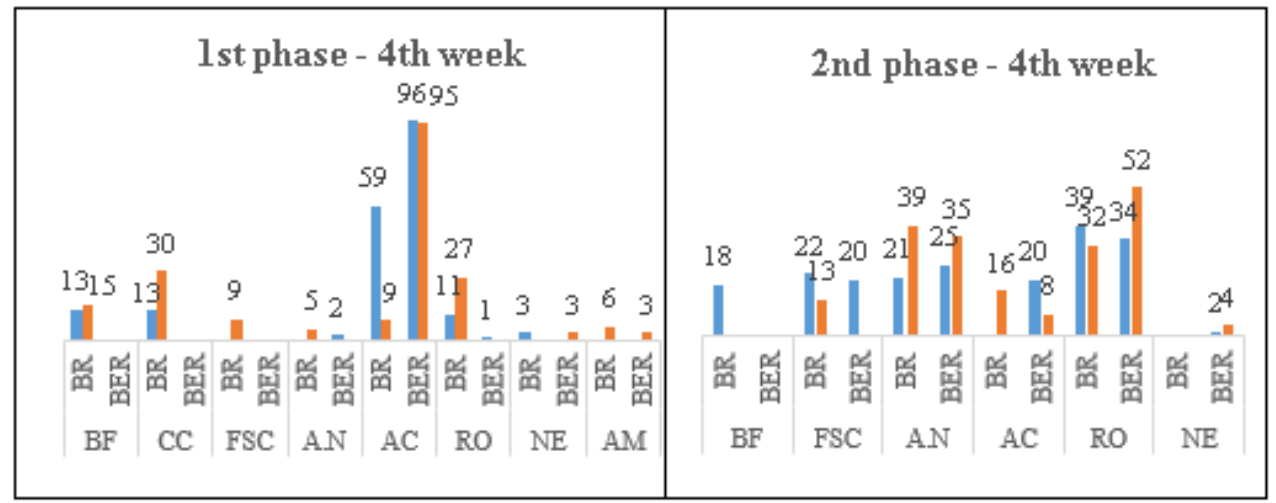

Figure 6. Microorganisms' relative frequency in the BR and BER during the fourth week of operation, corresponding to the fourth experimental condition applied. The labels of the organisms are in accordance with Table 4.

Finally, at the beginning of the fourth experimental condition, it was observed in the BER a diversity reduction of microorganisms (Figure 7). At the end of this period, the BER showed the same amount of species present at the beginning of this experimental condition for the attached ciliates. At the beginning of the fifth and final experimental condition evaluated, the annelids were the dominant group in the two reactors. At the end of the period, the BER reactor showed the highest reduction in the diversity of microorganisms presented in the biomass of this reactor, with only two species, rotifers and annelids, which can be associated to the negative effect of the electric current on the BER. It is suggested that there was interference of the electric current in the microbial metabolism in the first and second phase of operation. However, it cannot be stated to what extent electrostimulation of microorganisms positively or negatively affected the biomass.

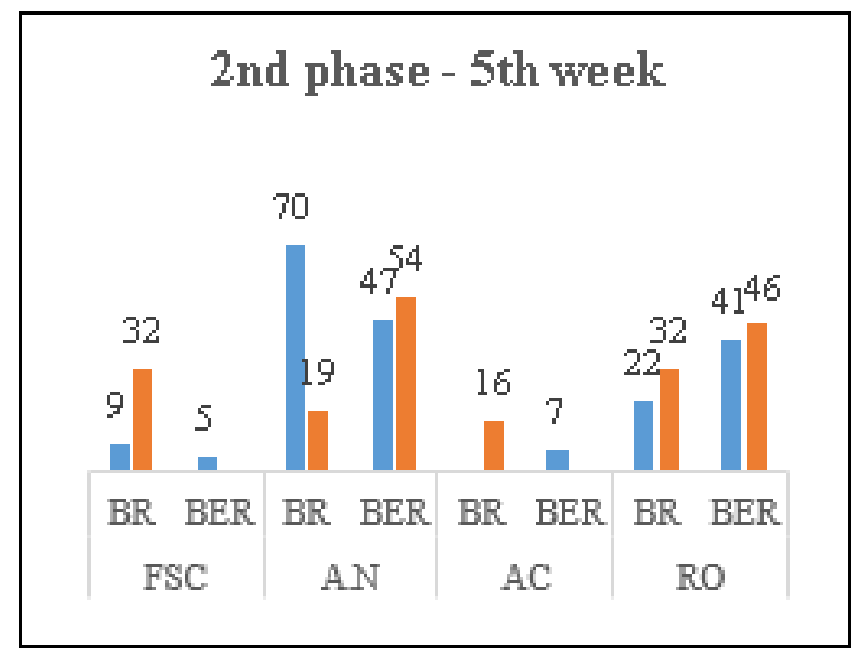

Figure 7. Microorganisms' relative frequency in the BR and BER of the fifth week of operation, corresponding to the fifth experimental condition applied. The labels of the organisms are in accordance with Table 4. 
In the first stage of operation, the formation of an iron hydroxide precipitate increased according to the increase of the applied electric current. Therefore, it is hard to make inferences from the COD values, since it is known that this analysis was impaired mainly in the last experimental condition with the highest electric current value tested. It can be suggested that the experimental conditions imposed on the BER reactor contributed to affect the zooplankton community. It can be affirmed that part of the oxygen that was being supplied to this reactor was consumed in the iron oxidation. Thus, it is probable that the aerobic degradation of organic matter and the nitrification process itself have been affected, reaching anoxic conditions in the system.

According to Thrash and Coates (2008), studies indicate that electrical stimulation can negatively affect growth and microbial activity; however, using appropriate currents, it is possible to promote microbial metabolism. Wei et al. (2011) demonstrated that the heterotrophic bacterial community was not significantly affected when the applied current density was less than $6.2 \mathrm{~A} / \mathrm{m}^{2}$, but was partially inactivated at current densities above 12.3 $\mathrm{A} / \mathrm{m}^{2}$. The current densities applied in the first and second phase of operation in this study $\left(0.0549,0.2747,0.5495,2.7473\right.$ and $\left.5.4945 \mathrm{~A} / \mathrm{m}^{2}\right)$ were lower than $6.2 \mathrm{~A} / \mathrm{m}^{2}$. Therefore, it would be expected that in the studied system there would be no immediate inactivation of microorganisms, a process that occurred gradually with the increase of the applied electric current. According to Matsunaga et al. (1992), electrical stimulation can cause negative effects on bacteria, directly oxidizing intracellular constituents without destroying their membranes, leading to cellular inactivation. High electrical current can also cause irreversible permeability of the cell membrane and subsequent release of essential cytoplasmic constituents (Drees et al., 2003). In addition, the literature indicates that electrolysis generates products derived from abiotic reactions on the electrode surface that may influence microbial metabolism, such as hydrogen peroxide, which may inhibit microbial metabolic activities (Thrash and Coates, 2008).

However, during the system operation, it was verified that the bio electrolytic reactor obtained similar values in terms of COD removal, and sometimes it was higher than the biological reactor. This may indicate a positive interaction between the zooplankton community in the bio electrolytic reactor and the electrical current application. However, it was not possible to state through this work that this interaction is beneficial for microorganisms.

\section{CONCLUSIONS}

The differences between COD removal in the bio electrolytic process during the two phases came from the different application of materials of the electrodes and due to the different origins of the inoculum used. The best results were achieved with rigid pure graphite electrodes, suggesting that non-reactive electrodes are more indicated for the process. According to the microbiological analysis, it was possible to identify that the zooplankton community was progressively affected due to electric current application in the bio electrolytic reactor during system operation. This fact was confirmed by the drastic reduction of diversity and relative frequency of the zooplankton community, indicating a possible electric current interference in the microbial metabolism during operation. With the design of the bio electrolytic reactor proposed in this research, this reactor did not reach sufficiently high organic matter removal efficiency when compared to the efficiency of the biological reactor to justify its application. However, even in this configuration (electrolytic and biological treatment in the same vessel), it is expected that such behavior can be improved when treating an effluent containing a toxic or recalcitrant compound.

As for the electrolytic reactor, the results suggest that, even under very low electrical currents, it was possible to achieve high COD removal rates under the conditions studied. It

Rev. Ambient. Água vol. 14 n. 4, e2349 - Taubaté 2019 
should be remembered that one of the criticisms of the electrolytic reactor treating sewage is that its energy consumption is supposedly very high.

In order to subsidize future works on the electrolytic and bio electrolytic treatment applied to the treatment of sewage, some recommendations are suggested. For example, a BER test in separate reactors, with the electrolytic treatment preceding the biological reactor and vice versa. In addition, it is also proposed to evaluate the bio electrolytic reactor efficiency in order to promote the degradation and removal of difficult compounds to treat.

\section{ACKNOWLEDGEMENTS}

The authors would like to express their gratitude for the financial support from the Brazilian agencies CNPq and FINEP and for the aid to the development of this research from the Brazilian Federal District's Water Supplier and Sanitation Company (CAESB).

\section{REFERENCES}

ACHAVAL, L. S. Desenvolvimento e avaliação de um protótipo de estação compacta para tratamento de esgoto em unidades residenciais unifamiliares. 2014. 191f. Dissertação (Mestrado em Tecnologia Ambiental e Recursos Hídricos) - Departamento de Engenharia Civil e Ambiental, Universidade de Brasília, Brasília, DF, 2014.

AL-SHANNAG, M.; BANI-MELHEM, K.; Zaid AL-ANBER, Z. Enhancement of CODNutrients Removals and Filterability of Secondary Clarifier Municipal Wastewater Influent Using Electrocoagulation Technique. Separation Science and Technology, v. 48, n. 4, p. 673-680, 2013. https://dx.doi.org/10.1080/01496395.2012.707729

APHA; AWWA; WEF. Standard Methods for the Examination of Water and Wastewater. 21. ed. Washington, 2005.

CAESB. Sinopse do Sistema de Esgotamento Sanitário do Distrito Federal. 26. ed. 2013. Available at: https://pt.scribd.com/document/340216176/SIESG-2013-Para-Intranet. Access: 04 Feb. 2018.

CANLER, J. P.; PERRET, J. M.; DUCHENE, F.; COTTEAUX, E. Aide au Diagnostic des Stations d'Épuration par I'observation Microscopique des Boues Activées. Lyon: Cemagref Editions, 1999. 160p.

CHONOVA, T.; KECK, F.; LABANOWSKI, J.; MONTUELLE, B.; RIMET, F.; BOUCHEZ, A. Separate treatment of hospital and urban wastewaters: A real scale comparison of effluents and their effect on microbial communities. Science of the Total Environment, v. 542, p. 965-975, 2016. https://dx.doi.org/10.1016/j.scitotenv.2015.10.161

CLARO, E. M. T.; OTENIO, H. M.; BIDÓI, A D. E.; SILVA, G. M. M. N.; SANTOS, V. Avaliação em escala laboratorial da aplicação do processo eletrolítico em efluente de lagoa de estabilização de esgoto urbano. Química Nova, v. 33, p. 557-561, 2010.

DAGHRIR, R.; DROGUI, P.; TSHIBANGU, J. Efficient treatment of domestic wastewater by electrochemical oxidation process using bored doped diamond anode. Separation and $\begin{array}{llllll}\text { Purification Technology, } & \text { v. 131, p. } & \text { 79-83, }\end{array}$ https://dx.doi.org/10.1016/j.seppur.2014.04.048

DREES, K. P.; ABBASZADEGAN, M.; MAIERA, R. M. Comparative electrochemical inactivation of bacteria and bacteriophage. Water Research, v. 37, p. 2291-2300, 2003. https://dx.doi.org/10.1016/S0043-1354(03)00009-5 
GARCIA-SEGURA, S.; OCON, D. J.; CHONG, N. M. Electrochemical oxidation remediation of real wastewater effluents - A review. Process Safety and Environmental Protection, v. 2, n. 3, p. 48-67, 2018. https://dx.doi.org/10.1016/j.psep.2017.09.014

GANZENKO, O.; HUGUENOT, D.; HULLESBUSCH, V. E.; ESPOSITO, G.; OTURAN, A. M. Processos Eletroquímicos de Oxidação Avançada e Biológicos para Tratamento de Águas Residuais: Uma Revisão das Abordagens Combinadas. Environmental Science and Pollution Research, v. 21, p. 8493-8524, 2014. https://dx.doi.org/10.1007/s11356014-2770-6

LIU, L.; ZHAO, G.; PANG, Y.; LEI, Y.; GAO, J.; LIU, M. Integrated Biological and Electrochemical Oxidation Treatment for High Toxicity Pesticide Pollutant. Industrial and Engineering Chemistry Research, v. 49, p. 5496-5503, 2010. https://doi.org/10.1021/ie100333v

MADONI, P. A sludge biotic index (SBI) for the evaluation of the biological performance of activated sludge plants based on the microfauna analysis. Water Research, v. 28, p. 6775, 1994. https://doi.org/10.1016/0043-1354(94)90120-1

MARTÍNEZ-HUITLE, A. C.; RODRIGO, A. M.; SIRÉS, I.; SCIALDONE, O. Single and Coupled Electrochemical Processes and Reactors for the Abatement of Organic Water Pollutants: A Critical Review. Chemical Reviews, v. 115, n. 24, p. 13362-13407, 2015. https://dx.doi.org/10.1021/acs.chemrev.5b00361

MATTIUSI, E. M.; KAMINARI, N. M. S.; PONTE, M. J. J. S.; PONTE, H. A. Behavior analysis of a porous bed electrochemical reactor the treatment of petrochemical industry wastewater contaminated by hydrogen sulfide. Chemical Engineering Journal, v. 275, p. 305-314, 2015. http://dx.doi.org/10.1016/j.cej.2015.03.138

MATSUNAGA, T.; NAKSONO, S.; TAKAMUKU, T.; BURGESS, J. G.; NAKAMURA, N.; SODE, K. Disinfection of drinking water by using a novel electrochemical reactor employing carbon-cloth electrodes. Applied and Environmental Microbiology, v. 58, p. 686-689, 1992.

MICHELAN, R. Influência do tipo de impelidor sobre o desempenho do reator anaeróbio em batelada sequencial com biomassa granulada tratando esgoto sintético. 2006. 181 p. Dissertação (Mestrado) - Escola de Engenharia de São Carlos, Universidade de São Paulo, São Carlos, 2006.

MOURA, B. R. Desempenho de um reator vertical de fluxo contínuo e leito estruturado com recirculação de efluente, submetido à aeração intermitente, na remoção de carbono e nitrogênio de um efluente sintético. 2011. 92p. Dissertação (Mestrado) Escola de Engenharia de São Carlos, Universidade de São Paulo, São Carlos, 2011.

RADJENOVIC, J.; SEDLAK, D. L. Challenges and Opportunities for Electrochemical Processes as Next Generation Technologies for the Treatment of Contaminated Water. Environmental, Science \& Technology, v. 49, n. 19, p. 11292-11302, 2015. https://dx.doi.org/10.1021/acs.est.5b02414

RODRIGUES, M. C.; BRITO, S. R.; SINOTI, A. L. L.; SOUZA, M. A. A. 2001 Tratamento eletrolítico de efluentes de efluentes de reatores anaeróbios. In: CONGRESSO BRASILEIRO DE ENGENHARIA SANITÁRIA E AMBIENTAL, 21., 2001, João Pessoa. Anais[...] São Paulo: ABES. 2001. p. 1-34. 
SANTOS, V. A. Comportamento de um Reator Sequencial de Batelada (SBR) sob estado estacionário dinâmico utilizando a idade do lodo como parâmetro de controle operacional. 2005. 418p. Tese (Doutorado) - Universidade Federal do Rio Grande do Sul, Porto Alegre, 2005.

SENTHILKUMAR, S.; BASHA, A. C.; PERUMALSAMY, M.; PRABHU, H. J. Electrochemical oxidation and aerobic biodegradation with isolated bacterial strains for dye wastewater: Combined and integrated approach. Electrochimica Acta, v .77, p. 171178, 2012. https://dx.doi.org/10.1016/j.electacta.2012.05.084

THRASH, J. C.; COATES, J. D. Review: direct and indirect electrical stimulation of microbial metabolism. Environmental Science Technology, v. 42, n. 11, p. 3921-3931, 2008. https://dx.doi.org/10.1021/es702668w

TORRES, P. L.; FORESTI, E.; VAZOLLER, R. 1996 Composición y uso de agua residual doméstica en reactores a escala de laboratório. In: CONGRESSO INTERAMERICANO DE INGENIERÍA SANITARIA Y AMBIENTAL, 25., 1996, Cidade do México, Anais[...] México: AIDIS, 1996. p. 1-9.

USEPA. Process design manual for nitrogen control. Cincinnati, 1993. EPA/625/R-93/010/.

VON SPERLING, M. Lodos ativados: Princípios do tratamento biológico de águas residuárias. Belo Horizonte: UFMG, 1997. 415p.

WEI, V.; ELEKTOROWICZ, M.; OLESZKIEWICZ, J. A. Influence of electric current on bacterial viability in wastewater treatment. Water Research. v. 45, p. 5058-5062, 2011. https://dx.doi.org/10.1016/j.watres.2011.07.011 